\title{
Geography, democracy and administration issue in the Middle East
}

\author{
Hamza Akengin ${ }^{1}$, Hatice Kubra Gurcay ${ }^{2}$ \\ ${ }^{1}$ Department of Geography, Faculty of Arts and Sciences, Marmara University, Istanbul, Turkey \\ ${ }^{2}$ Institute of Middle Eastern Studies, Marmara University, Istanbul, Turkey \\ Email address: \\ hamzaakengin@yahoo.com (H. Akengin),gurcaykbr@hotmail.com (H. K. Gurcay)
}

\section{To cite this article:}

Hamza Akengin, Hatice Kubra Gurcay. Geography, Democracy and Administration Issue in the Middle East. Humanities and Social Sciences. Vol. 2, No. 2, 2014, pp. 23-32. doi: 10.11648/j.hss.20140202.13

\begin{abstract}
The Middle East has been one of the most controversial regions in the world since the late $19^{\text {th }}$ century and early $20^{\text {th }}$ century due to ethnical, political and religious diversity, administration problems, historical disputes, oil and natural gas reserves, status of being outside the global economic and political system and hot combats. Now, at the end of the first decade of the $21^{\text {st }}$ century, the most significant reason behind the events centrally in the Middle East, particularly in the Arabian states, is regime of the countries in the Middle East. In the countries of the Middle East, restriction of the democratic rights, one-person powers for long years and lasting many decades, limited engagement in the politics in almost all countries, prevention of political engagement, oppressive and restrictive regimes, hereditary authoritarian administration isolated from the society all have triggered social movements. This study concerns relationship between geography and democracy, specifically in the Middle East, emphasizing the fundamentals on which the regimes of the Middle East Countries are based. Intending to determine the situation, this study is based on documentary analysis and description.
\end{abstract}

Keywords: Geography, Democracy, Regimes in the Middle East, Monarchy, Tribe

\section{Introduction}

Given the geographical conditions of the Middle East with its controversial borders, it is a region under the effects of very different climates from very hot desert conditions such as Nufud in Saudi Arabia, Sahara Desert in Egypt, Dasht-i Lūt and Dasht-e Kavir Deserts in Iran on the one hand and Turkey showing effects of four seasons at the same time and Mediterranean shores with subtropical climactic conditions on the other hand. As to the geographical features, there are flat or slightly inclined fields such as occasional coastal plains, infinite plateaus as well as significant rugged terrains and mountain ranges consisting of young mountains formed in connection with Alpine-Himalayan orogeny; North Anatolian mountains, Taurus mountains, Zagros mountains. In terms of human condition or historical past, the Middle East includes Mesopotamia, one of the first important settlements in the world, Nile and eastern Mediterranean coasts. Furthermore, it has a remarkable history in that Middle East was on the silk and spice routes, the first important trade routes in the world, and it has a history of civilization that witnessed the fist written laws (Hammurabi Laws established by the king of Babylonia, BC 1760) and lots of inventions and principles that have profoundly shaped the human history. Additionally, the Middle East is the origin of and starting point for spread of the monotheistic religions that have inspired the humanity for rights and law.

When a map indicating regimes worldwide in the beginning of the $20^{\text {th }}$ century is examined, it will be obviously seen that monarchic administrations were widespread and there were only a few countries with multiparty democracy. Forms of limited democracy existed in the countries such as USA and United Kingdom. In the mentioned period, the most common regimes around the world were absolute monarchic systems consisting of kingdoms, Czardom and empires (Fig. 1). A significant part of the world was under the hegemony of the colonialist states. As a result, the United Kingdom with the lands under its hegemony, spreading over thousands of kilometers in the eastern, western, southern and northern directions, was named as "the empire on which the sun never sets". 


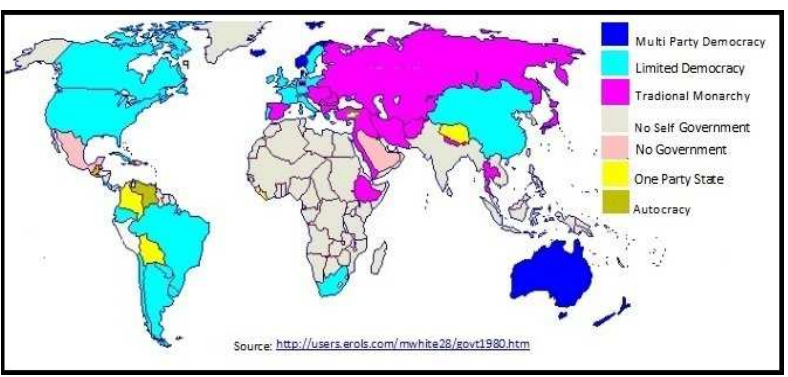

Figure 1. The general dispersion of governmental systems on the world at early $20^{\text {th }}$ century.

Likewise, the colonies of France had been covering an area of hundred thousands of square kilometers worldwide with South America in the west to Vietnam in the east. And now, when we look at a map indicating regimes in the beginning of the $21^{\text {st }}$ century, it will be apparent that the regimes basing on democracy have spread in the course of time and the primary countries ruled by absolute monarchy in the beginning of this century are in Africa, Middle East and Middle Asia (Fig. 2), [1]. Despite of the trend of the spreading democracy, the countries with limited democracy today are also in Africa, Middle East, Caucasia and Middle Asia. It should be understood that each country ruled by rules of limited democracy have their own specific characteristics. For example, while the African countries have remained under the colonialist administration for a long time, the Middle Asian countries have experienced communist ideological applications based on single political party for 70 years. One can observe that the African countries, particularly the countries of the Middle East, have gained their independence as a result of the conjectural conditions after the World War II. And upon sudden disintegration of the Soviet Union in 1991, the Middle Asian countries have found themselves independent suddenly. The fact that no democracy culture has evolved historically in both the Middle Eastern countries and Middle Asian countries constitutes the root of the administrative problems in these countries. From an overall perspective, the Middle East and North African countries are considered as areas where limited democracy applications are seen as consequences of both the structure shaped by the colonialist activities and social structure.

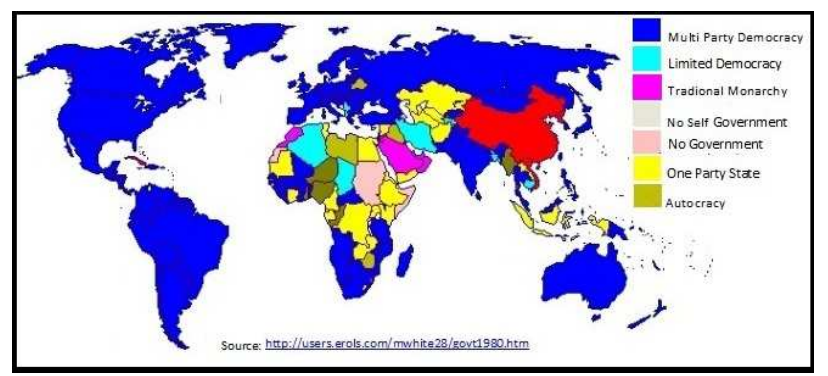

Figure 2. The general dispersion of governmental systems on the world at early $21^{\text {th }}$ century.

This study tries to discuss the fundamental and foregrounding problems related to the general public living in Middle East, failure to contribute to the administration and how powers with different qualities and power sources create administrations to protect their own interests as well as the reasons for the failure to establish democratic structures, all in connection with the geography. To understand the reasons underlying lack of democracy, it is essential consider political structures of the major countries in the region and about the historical process on which that structure is based. The regime problem in the local countries is, therefore, also the problem of the existence of an antidemocratic system. For this study, some academic studies have been examined from the current resources; the resources sharing information about the political institutions of these countries have been scanned and, especially, the regimes of the countries in the region and their reflections on the societies have been described to discuss the existing problems concerning the issue of democracy.

\section{Objective and Method of the Study}

This study tries to discuss the fundamental and foregrounding problems related to the general public living in Middle East, failure to contribute to the administration and how the powers with different qualities and powers source create administrations to protect their own interests as well as the reasons for the failure to establish a democratic structures, all in connection with the geography. In this context, the objective of the study is to scrutinize the relationship between geography and democracy and analyze whether there is any relationship between the regimes of the countries in the Middle East and specific geographical conditions. We shall seek answer to two questions in this respect. While one of them is the question "is there any relationship between geography and democracy?", the second one that relates the geography to both physical conditions and human and economic conditions of a space unit is "do the geographical conditions have any effect on the under-development of democracy in the Middle Eastern countries?". Consequently, the objective of this study is to determine the position. The data used in the study has been obtained by literature scan and documentary analysis. Descriptions also have significant share in the assessments made. Some comparisons have been made to explain the subject matter and the relationship between the national income resources and regimes in the Middle Eastern countries as well as specific religious and racial qualities of the region were emphasized and comparisons have been made to conclude in connection with the relationship between the geographical conditions and democracy. In this context, academic studies particularly consisted of current references have been examined; the resources sharing information about the political institutions of these countries have been scanned and, especially, the regimes of the countries in the region and their reflections on the societies have been described to discuss the existing 
problems concerning the issue of democracy.

\section{Geography and Democracy}

It is pointed out that the geographical conditions affect economic and social factors, thus assisting development of the democracy [2]. It is recognized that the geographical conditions are among the power resources of a state. When the local and foreign policies of the states are examined, the effects of the geographical factors are obvious. It is known that there is a relationship between administrative structure of the states, establishment of the development areas, preferences determining the transportation systems and the physical geographical conditions [3].

Natural conditions have significant effect on the political structure of the countries. In Caucasia, for example, the relationship between the distribution of the ethnical groups and suitability of the geographical features for settlement is quite evident. Egypt, a Middle Eastern country, has an area of about $1,000,000 \mathrm{~km}^{2}$. It is the most populated country in the Middle East with its population about 83 million and almost all of this population has settled in the basin and delta of the Nile. Consequently, the main factor determining the distribution of the population in Egypt is water and the fertile alluvial deposit as a result of the flood of the Nile, one of components of the physical geography.

As it is known, several factors have effect on the determination of the borders separating the states as well as the countries of different political understanding. By way of example, we may give Turkey-Iran border in the Middle East. The border separating these two countries follows the water-separation line of the Zagros range of mountains. On the other hand, it is also known that some borders are determined by decisions taken on the table, instead of physical geographical conditions. The artificial borders determined on map and conference table are generally applicable in an area with colonization background, sparsely populated lands and places without any detailed geographical information about the border zone, deserts having no land value and Polar Regions [4]. When we examine a map showing the Middle Eastern countries politically, it is seen that the borders separating the countries are consisted of straight lines following the latitudes and longitudes or lines linking two points. Consequently, for most of the Middle Eastern countries, the borders separating the states have been determined according to the political factors.

That the geographical conditions are among the power resources of a state is something related to the range of area, underground and ground resources, geopolitical position and human potential. Although, when the East is taken as a whole, some countries have appropriate conditions in terms of some physical geographical resources, important part of the countries have negative aspects with respect to the physical geographical conditions. In other words, while the countries such as Saudi Arabia, Iran and Iraq have rich oil resources, they also have wide span of desert areas. Both of them are related with the physical geography. Egypt has Suez Channel and the Nile. While Suez Channel makes Egypt important geopolitically, the Nile is the origin of the Egyptian civilization. However, it is also a fact that deserts cover a great area in Egypt. Suez channel, Nile and Egyptian Deserts each are geographical facts.

It is also known that the peoples that populate the Middle Eastern countries have characteristics very different from each other. Differences between the peoples populating this region include ethnical origin, religion and sects, city and urban distribution of the population and the tribes or tribes to which they belong. We may say the picture illustrated above generally by physical and human conditions gives us important hints to understanding the regimes.

After the mid of the 20th century, the world witnessed two important developments. As first, is the previously colonial states have gained their independence. Second development is the quick spread and globalization of the democracy when compared with the previous periods. Democracy is formation of the political rules by the people's own will. Democracy also contains whole processes and procedures where the political institutions are established by the public's will. Free and fair elections, civil freedoms and political engagement are primary conditions required for democracy. All of them also constitute democratic political culture.

By the end of the World War I and particularly in the years subsequent to the World War II, the process of gaining independence over the world generally and in the Middle Eastern countries particularly has resulted in breaking away of the Middle Eastern countries from the colonialist administration in 1970s. The states that gained their independence from the colonialist administration in almost all parts of the world have been governed by authoritarian regimes so that continue the structure previously established by the colonial states has been continuing. This condition is applicable for the Middle Eastern countries as well.

In the course of time, either democratic customs have evolved or various forms of regimes from developed or limited democracy to absolute monarchy have started to be dominant in the Middle Eastern countries, depending on their own specific conditions.

When the Middle Eastern countries are considered as a whole, we notice some institutions and rules of the democracy worked in some countries. For instance, Turkey, Lebanon and Israel are the Middle Eastern countries where democratic applications have been implemented. While there is multi-party political structure in some countries such as Iraq, Syria and Egypt, we actually find a structure based on single party government. Upon the US occupation of Iraq, the political structure based on single party government has changed in this country. Movements started by a process called Arab spring for democratic requests in Syria and attitude shown by the Syrian government for suppression of these movements have caused outbreak of civil war in Syria. As to Egypt, due to 
the military coup against the elected president and ongoing uncertain conditions, it is very hard to make proper assessment in this respect. While there is constitutional monarchy in Jordan, we see absolute monarchic regime in the Gulf countries. In Iran, one of the most populated countries in the Middle East, we notice both a limited democracy and a theocratic structure. Saudi Arabia has oligarchic, theocratic and absolute monarchic regime. When considered overall, it is observed that each country in the Middle East has developed a different type of regime as a result of its own geographical and historical conditions.

In the Middle Eastern countries, the authoritarian regimes rather than those based on democratic foundations stand out. In the region, the countries governed by authoritarian regimes show similar characteristics. Among such similarities are violation and lack of basic freedoms, widespread corruption, favoritism and ownership and management of the income resources by a small minority. Furthermore, static economy, low per capita income, high employment, civil service as primary field of employment, high and increasing trend of inflation in these countries may also be cited among similarities in terms of economy. Young population, authoritarian administration and administrative authorization descending from father to son are also shared characteristics [5].

Looking at the world globally, some countries seem to have more democratic structures than others in terms of administration. When closing at the reasons underlying this fact, two opinions appear: economical development or modern society structure and powerful social engagement. There are four countries in contrary to this explanation: Kuwait, Burnei, Bangladesh and Morocco [6]. Although Kuwait and Burnei have high national income, monarchic structure is dominant. As to Bangladesh and Morocco, despite of powerful social engagement, the democratic customs have not developed in these two countries.

The responds of researchers to the question of why some countries are more democratic than others can be as two dominant approaches. The first approach emphasizes on economic diversity, economic development and income inequality; and the second on the socio-cultural factors. And there are also opinions combining socio-cultural and economic approaches. Another different approach claims that geography affects the democratic results. The geographical conditions of the countries especially constitute economic and socio-cultural diversity that affect the democracy. Geography affects advantages of the democracy in three ways: Income distribution, formation of social and civil society structure.

Civil society is present wherever the income is distributed equally, the superiority of law is effectively applied and the society is inclined to be organized at a horizontal level, and as a result, members of the society build relationship with each other more equally with democratic outcomes. And whenever the opposite case occurs, the social relationships established vertically constitute a hierarchical social structure [7].
Looking at the general qualities of the democratic countries worldwide, one of the common denominators of them is high national income. Many researches show that higher the national income, more democratic the regimes are. However, some scholars point out an exception to it. If national income of a country depends on the oil it drills and sells, the national income loses its characteristic effect on the development of democratic inclinations. The claim that oil and democracy do not match with other is frequently used to explain why the high income Middle Eastern countries may not be democratic [8]. If it is correct, then the reasons for the political problems in the countries such as Nigeria, Indonesia and Venezuela, oil exporters worldwide, may be explained from this perspective. However, the idea of oil impeding democracy has not been favored much.

Looking at the regions of dispute or collision worldwide, some common characteristics in terms of economy, politics and culture are noticed as reasons of such conflicts. In fact, at the root of these common characteristics lie the geographical and historical factors. Widespread antidemocratic applications are notices in the regions where authoritarian regimes rule and conflicts appear. It is emphasized that anti-democratic applications in connection with the geographical conditions and developments such as ethnical violence set back development of the democratic systems [9]. The scholars draw attention to the relation of the vegetable production and political power with the geography in most African countries, claiming that lower taxes are imposed on the vegetable production in democratic countries [10]. Consequently, it is understood that there is a relationship between geography and democracy. And geographers also signify relationship of the nature, distribution and spread of democracy in the historical process with the different economic systems [11].

When the countries ruled by democracy worldwide are studied, it is understood that actually the physical geographical conditions have no obvious effect on prevention of the democratic customs. Canada, for example, has a democratic regime, although it mostly remains in the cold zone. Brazil, with dominant tropical climactic conditions, is one of the countries where democracy works together with its rules and institutions. United Kingdom and Japan, island countries, are ruled by constitutional monarch and, actually, are cited among the countries where democratic customs have been deeply established with all its institutions and rules. Based on this data, it appears that physical geographical conditions do not necessarily impede development of democratic customs.

Looking at the Middle Eastern countries, the focal point of this study, as a whole, the conditions of physical geography and human and economic geography or conditions of physical geography and cultural geography come forward as effective in the determination of the type of administration. Consequently, human conditions shaped by the conditions of physical geography as well as the political culture established by it appear as a factor shaping regimes in the Middle East. 
Hosting different religions, ethnical characteristics and cultures, the Middle East is at such a position that it creates common civilization basin of the humanity, showing developments and changes that deeply affect the world history. The economic problems and instable political culture not established on a certain system and autocratic structure make this region quite problematic and full of conflicts, despite of the positive characteristics such as religious, cultural and ethnical diversities, rich underground and ground resources, oil and natural gas reserves. Strategic significance of the Middle East geopolitically has led many researches to the region. Allowing studies to be conducted in a wide spectrum of fields in terms of social sciences, the Middle Eastern countries have been discussed particularly in connection with political activities as it has gained more importance since 19th century. Interests of the West, particularly colonial countries, in these lands have motivated them to make research in a variety of fields related to this region. Oil that becomes a strategic material in the course of time and the presence of $60 \%$ of the world petrol reserves in this region on the one hand and desire of the developed countries to hold and control these resources on the other hand have created an environment laden with conflict both for the local people living in these lands and other societies globally.

\subsection{Administration Culture in the Middle East and Basic Factors Shaping Political Structure of the Nation- States}

In the period after the World War II, the process of gaining independence by the Middle Eastern countries has not resulted from the fight against the colonial power, but rather from the colonial state's own will. The rulers of the Middle Eastern countries which have become nation-states converted from the colonized state as a result of gaining independence have been the bureaucratic elite from the "top" of the state or those who have been supported by the colonial state or notables of the tribes which had collaborated with the colonial power, rather than being revolutionary figures basing on the public movement. Similar conditions have been experienced in all countries such as Saudi Arabia, Syria, Iraq, Egypt, Lebanon and Jordan. The greatest ideological component of the states is nationalism. As it is, because manifestations of the local political discussions in the public sphere are under pressure, the controlled use of nationalism works as an ideological tool of which the states avail themselves frequently. Even it could not overrule sustainability of the mechanism inherited from the colonial period [12].

After the Armistice of Mudros had been signed at the end of the World War I, a significant part of the Ottoman Empire in the Middle East were occupied by the United Kingdom and France and eventually, upon fragmentation of the Ottoman Empire with the Treaty of Lausanne, the Middle Eastern countries came under domination of the western countries. Reorganizing the state, bureaucracy and education in the countries they occupied, the British and French have brought to power the civil-military bureaucrats from the tribes or sects by collaborating with them.

After the World War II, the countries in the region started to develop institutional and political organizations economically and sustain their existence in political sense. Political or institutional structures that the Middle Eastern countries tried to build and develop have characteristics very similar to each other because the culture that has determined or shaped the political or institutional structure in these countries was majorly established by the colonial country. Consequently, same principles appear in the constitutions of the countries in general sense. It is observed that the regimes adopted by Egypt, Iraq, Syria Jordan, Yemen and the Gulf countries, that is, Saudi Arabia, Bahrain, Qatar, Kuwait, United Arab Emirates and Oman are based on the same foundations. The British and French, two colonial states worldwide, treated the peoples of their colonies as second class individuals. Whenever the societies attempted to recover themselves and express their existence, they were always suppressed violently by the armies of the colonial countries. As a natural consequence, this approach has also been adopted by the leading figures of the tribe that started to rule upon retreat of the colonial state. In the Middle Eastern countries, political organizations dominated by the tribes are noticeable. Based on the tribes, religion and sects shaped by the historical and geographical conditions, these political organizations are formed by the preferences of the top rulers and their close relatives. Such organizations helped presidents of the states remain in power throughout their lifetimes and when they became incapable to rule the country, they used to inherit the administration power of the country to their inheritors. In the countries where such approach and organization sustain, any movement by the discontented people was violently suppressed.

In all Arabian countries and most Islamic countries, the people couldn't directly affect the establishment of political organizations and their systems so far. Kings, dictators or presidents that came to power by means of sham elections all established mechanisms apt for maintaining their own dominance. Although the Middle Eastern countries were saved from the obvious invasion of the West, the economic, diplomatic, politic and cultural relations of these countries are primarily with the colonial countries because of the structure originally established by the colonial countries. The ruling elite, the civil-military bureaucracy has always been in close contact with the developed countries of the western world, particularly with the ruler country in the colonial period. This also means that the rulers have never taken into consideration the requests and expectations of the people with respect to national and international problems. Actions of administrations in form of inheritance from father to son, in form of royalty or in the regimes established by military coup have changed and responsible authorities have been overthrown in the course of time. However, those that got hold of the administration authority by coup have always been keeping the public from the administration mechanism. Those keeping the administration authorization in hand in the established 
constitutional structure have developed such a mechanism as to ensure maintenance of the power of their own descendants. Hafez al-Assad in Syria, Hasan, Moroccan King, in Morocco and Hussein, Jordan King, for example, have established such a structure to bring their sons to power, Beşar Assad, Mohammed VI and Abdullah, respectively. And the presidents of the states in Yemen, Libya and Egypt have also made constitutional adjustments and created political environment to ensure their sons to become presidents after them [13].

\subsection{Democracy and Status of the Administrations in the Middle East}

Modern representative democracies are defined as "self government" or government of the public by the persons elected by the public. In a democratic government, the source of governing power belongs to all citizens called "public". There are mandatory principles to establish a democratic government structure. These include popular sovereignty, free and regular elections, political pluralism and competition, majority rule and minority rights, civil, political and economic freedoms, assurance of basic human rights, legal egalitarianism and restriction of the government by constitution and independent judiciary [14]. Existence of elections only, without assurance of freedom and independent judiciary would result in "majority dictatorship". In a democracy, the requirements of justice and freedom should be assured institutionally. In order that democracy may operate, it is essential that the persons with different interests and different opinions in the society are allowed to organize and easily defense their rights amicably [15]. In the countries ruled by sham democracy, this mechanism is not developed or not allowed to develop.

Looking at the political regimes widespread in the Middle East, it is observed that democracy together with its institutions and rules is not available and that there are different reasons for the fact that authoritarianism has become the frequent regime. Popular discourse in the West with respect to unavailability of democracy in the Middle East is the lack of democracy culture in the peoples of the Islamic world, effect of the Islam and weakness of the social structure for political formation. On the other hand, in contrary to this opinion, it is pointed out that weakness of democracy in the Middle East is directly caused by the attitudes of the regimes [16]. This effect is such a detrimental effect that that authoritarianism has become the dominant regime in the countries of the region. The ruling people have exclusive power to control the national resources and the people have no say in this respect. In fact, it should be seen as reflection of the attitude in the colonial period in the present time because the colonial power had never made the local power involve in the decision-making mechanism with respect to use or investment of the local resources. This culture originally established by the colonial states was also maintained subsequently by the ruling statesmen in the region.

\subsection{Political Structure and Characteristics of the Middle East}

Just like the economic and social structure, politic structure of the Middle East shows diversity and variability. Muslim identity is not a monolithic one: the religious communities are divided into different religious sub groups, sects and trends in themselves. Middle East is almost always associated particularly with monarchs, theocratic states, oligarchic structure, limited democracy, weak democratic practices, antidemocratic regimes, coups, one-man rules, military, single party or family dictatorships. Significant disagreements in this field naturally lead to political instability, regional conflicts and serious problems [20].

Some international organizations assess the countries by the criterion whether their regimes are based on the democratic customs or not. The Economic Intelligence Unit is one of them. The criteria taken as basis by the Economics Intelligence Unit to form the democracy index are based on three important categories: election process and pluralism, civil rights, function of the government, political engagement and political culture. According to the 2012 data of Index of Democracy, the Middle Eastern countries take place in the category of countries with authoritarian regime, ranking in the lowest lines in the list of democratic countries. Kuwait, United Arab Emirates, Saudi Arabia, Iran and Bahrain are countries ruled by authoritarian regime and thus included in the group of countries at the end of the list [21].

Looking at the political structure of the primary countries, the administration of Iraq Republic, gained its independence from the United Kingdom in 1932, was started to be held under control by Saddam Hussein in 1968 in form of a single-party dictatorship [22]. Authority of Saddam Hussein through Ba'ath, the political party taking its power from the majority Arabs and Sunni minority continued till intervention of the coalition power led by the US on March 20, 2003 [23]. With reorganization of the political structure in the period after the US intervention, the country switched to the electoral system. Jalal Talabani from the Kurds that constitute $15-20 \%$ of the population was elected as President with an intention to bring a federal structure to the country. This federal structure covers ethnical regions, including the groups of Arab-Shiah, Arab-Sunni and Kurdish-Sunni.

Syria became independent in 1946. Syria has a population of about 22 million, consisting of Arabs about by $90 \%$ and Kurds, Armenian and other groups by $10 \%$. As to religious belief, the population consists of Sunni by 74, other Muslim groups, particularly Durzi by $16 \%$ and Christians and other groups by $10 \%$. The ruling political party, Ba'ath, in Syria was established basing on socialist ideology. However, as the socialist ideology is not favored by the Arabian world, Ba'ath Party has switched to adoption of an Arabian nationality. Nusayris accounting for about $15 \%$ of the Syrian population hold the administration authority in their hands in Syria. From its gaining independence so for, Syria has continuously witnessed military regimes and single party administrations. Although this country seems instable in terms of internal 
policy when looked externally, it is one of the most important and stable countries in the Middle East with respect to the regional policies. Although there is a multi party system in the Constitution in Syria, Ba'ath Party seems to come forward as a dominant power. Syria is governed by the Constitution put into effect on March 14, 1973. The Constitution defines the administration of the country as "socialist people's democracy". 1973 Constitution grants comprehensive powers to the president. The President has the authorization to assign the prime minister and ministers and declare war, state of emergency and blanket amnesty. Legislative prerogative belongs to an elected 250-member parliament. In all levels of the administration in Syria, the tribal and family relations come into prominence. Qabilain Tribe to which Assad holding the administration in Syria and his family belongs is one of the four most important tribes of Nusayris in Syria. The members of this tribe hold key duties in the basic institutions of the government and bureaucracy. Tribal and denominational solidarity among the Nusayris who are particularly dominant in the army and intelligence institutions is a significant determinant for the control of the power by Ba'ath Party. Governments that have failed both in the field of political freedoms and economic welfare suppressed any discontent supported by ethnical and religious reasons by violent and harsh methods. The process called the Arab Spring that has affected the Arab world and involved with democratic requests drove Syria to a civil war.

As a result of its position, Lebanon has a complex religious and ethnical structure. And as a natural consequence, its political system is also complex. The political structure in Lebanon is based on share of the political structure and positions among the religions and sects in proportion to their population. The established political structure requires that President should be Maronite, Speaker to be Shiah, Prime Minister Sunni and the power be shared on basis of 6 Christians - 5 Muslims. With change of the population in favor of Muslims over time, the Muslims requested more rights in the government of the country and equal representation in the Assembly in the early 1970s. Increased number of Palestinians that settled in Lebanon due to Palestine problem has been effective in the change of this demographic structure. Change in the distribution of the ethnical groups in the population was tried to be settled by the "Taif Agreement". With the "Taif Agreement", the powers of the Christian president were made restricted; number of Christian and Muslim members of the parliament was made equal and divided in themselves on basis of sects. However, the political power dispute between religions and sects still continues [24].

In terms of general ethnical and cultural structure, the population of Iran, dominated by Sii and Farsi culture, consists of Persians by $51 \%$, Azeri by $24 \%$, Gilaki and Mazandarani by $8 \%$, Kurds by $7 \%$, Arabs by $3 \%$ and groups such as Lurs and Turkmen rest of it [25]. Iran is governed by a theocratic republic taking its constitutional power from religion and an electoral system. Although Iran has an electoral system, it also shows an oligarchic structure because of the decision-giving body consisting of Ayetullahs which determines who may participate in the election. The political structure in the Iran Islamic Republic is based on the constitution established in 1979 after the Iran Revolution. There is a religious leader at the highest position of the political system. Iranian religious leader is responsible for definition and supervision of the general policies of Iran Islamic Republic. The religious leader is also the Chief Commander of the armed forces. 6 members of the 12member Constitutional Protection Council are assigned by the religious leader. Iran President is the highest state authority after the religious leader. Presidential candidates should be definitely approved by the Constitutional Protection Council to make sure about their loyalty to the ideals of the Islamic revolution. That the presidential candidates should be definitely approved by the Constitutional Protection Council has caused Iranian democracy to be defined as limited democracy.

In Egypt, one of the most important countries in the Middle East in historical and civilization terms, the President Mobarek had to resign as a result of protests in Tahrir Square that started in January 2011 and lasted for two weeks as a consequence of movements that started in Tunis and spread eastward for requests of freedom and democracy. This historical event for the Egypt, called "Tahrir Revolution" or "January 25 Revolution" was the start of a new period. As a subsequent of the general elections made in late 2011 and early 2012, People's Assembly and Council were established and President was elected to switch to a democratic process. As a result of the democratic elections, Mohammed Mursi was elected as President. However, the Egyptian arms has staged a coup on July 3, 2013 and removed the President from his position. These events which occurred in a period of two years approximately are important to understand depth of the democracy and administration problems in the Middle Eastern countries.

With its different religious and ethnical structure compared to other countries in the region, Israel is a country ruled by parliamentary democracy system. Having no constitution, Israel has been ruled by "Basic Laws" since the date of its establishment. Israel parliament (Knesset) consists of a single council of 19 members. Elections are held once in four years on basis of secret election and proportional representation. In Israel, the whole country is considered as the single electoral area and each citizen turning 18 years has the right to vote and each citizen turning 21 years has the right to stand for election. In the general elections, the national minimum percentage is $2 \%$ [26]. Political regime of Israel complies with the principles of democracy.

Middle Eastern countries of Saudi Arabia, Bahrain, Qatar, Jordan and Oman are traditional monarchs ruled by the families [27]. In Saudi Arabia, Saudi family rules the country. The political system in Arabia has been designed based on tribes, clans and religious institutions. Likewise, the business circles, media and sport clubs are organized based on tribes and clans. That Saudi Arabia maintains its 
stability despite of general instability in the Middle East is related with the movement of these groups under its protection. Saudi Arabia is monarchic due to passing of the governing power from father to son; oligarchic as the Saudi family holds the administration in its hand and theocratic as the constitution is based on Quran.

Gained its independence on December 16, 1971, Bahrain is ruled by el-Khalif family. Since the independence of Bahrain, important part of the governmental works has been performed by the Family Council consisting of elKhalif family. In Bahrain, almost all ministers and top level bureaucrats are members of el Khalif family.

Gained its independence after retreat of the British in 1970, Qatar is a governed by a monarchic system called "Emirate" in the hands of Al-Thani Family. According to the constitution adopted in 1970, there is a 35 -member advisory council with a limited legislative power. However, members of the advisory council are not determined not by election, but by assignment.

Jordan is administrated by Hashemite family and Oman by Qaboos family. Jordan is ruled by kingdom and Oman by Sultanate. While, out of these monarchs, Saudi Arabia, Bahrain, Qatar and Oman each are absolute monarchs, Jordan is ruled by constitutional monarchy [28]. The most important common characteristic of the Gulf countries is that they have a monarch system and each Gulf country is administered by a dynasty/family/tribe.

In the Gulf countries, those holding the economic and politic power in the country are in general sense the elite class and ruling families. Living an isolated and privilege life against other circles of the public, these families have developed alliance and security relations mostly with foreign powers in order to keep the power in their hands. Holding an Islamic understanding called traditional Bedouin Islam, these countries display a status quo attitude to keep the traditional structure and Islam is experienced both in the form of religion (cultural and social life) and government (political life). Consequently, opposition to the regime in these countries means opposition to the religious principles and values. The political regime in the Kingdom of Saudi Arabia is also based on the religious power of the Sheikh family providing legitimacy in addition to the political power of the Saudi family [29].

Due to the strategic natural resources they acquired after their independence, the Gulf countries come into prominence as important countries both in their region and before the global forces. In addition to the similarities among the Gulf countries in terms of their geographical positions, political regimes, economic resources and social structures, they also bear similarities with respect to internal political and institutional structures. The fact that the Gulf countries are rich in terms of natural resources and other countries are lack of natural resources has been a factor affecting political regimes of the countries. Oil-rich countries in the Middle East comply with the "Rentier State Theory". According to this theory, the state gets income mostly not from the domestic resources (tax, etc.), but from the sale of natural resources such as hard stone, oil, natural gas and tree to the foreign countries. External rent may change both development way and political structure of the country. Political systems of these countries have to do with maintenance of the rent. The reason is that the renter states are distributing states, rather than producing states. After obtaining high level of rent from the oil after 1970s, the Middle Eastern countries started to keep their citizens exempt from tax. No or low imposition of tax is not an application exclusive to the countries producing oil. No widespread tax collection system has developed in the countries such as Syria and Egypt. Lack of tax system seems to have created economic and political effects. In these countries, the state has become independent from the people as a result of the discourse "No tax, no representation" [30]. No taxation of the people eliminates accountability. If the people paid tax, then they would want to have a say in the administration because they would finance the public expenditures and bring the administrations to account and defend their cultural and economic rights.

\section{Conclusion}

Of two questions this study tries to answer, the first one is whether there is any relationship between geography and democracy. If we make an assessment on the basis of the study, it is understood that geographical conditions affect economic and social factors, assisting development of the democracy. Furthermore, it is evident that the geographical conditions are among the power resources of the states and, that the geographical effects are obvious when the internal and foreign policies of the states are examined. There is relationship among the administrative structure of the states, establishment of the development zones, preferences determining the transportation systems and conditions of physical geography. Consequently, when assessed generally, it is understood that there is relationship between the geography and democracy and that the geographical conditions set the stage for development of the democracy.

The second question this study tries to answer is whether the geographical conditions have any effect on the underdevelopment of the democracy in the Middle Eastern countries. When the conditions in the Middle East are taken into consideration, it is expected that the conditions should have a supportive effect on the democracy in accordance with the general tendency. However, it is observed that the situation in the Middle East does not comply with the general tendency. The Middle Eastern countries appear to have very different characteristic from each other in terms of geographical conditions. And even the countries having similar geographical conditions in the Middle East have different political applications. Consequently, it is observed that the human conditions shaped by the conditions of physical geography are effective in the formation of the political culture from the perspective of the conditions of the general geography 
and, as a result, very different structures have emerged in the Middle East with respect to the political culture and democracy applications.

When the regional countries are examined in terms of the conditions of physical geography in this study that deals with the Middle Eastern countries in terms of the relationship between geography and democracy, it is particularly seen that the countries having rich underground resources and the countries being devoid of them bear similarities in terms of the political structure. In the Gulf countries that account for major part of the Middle East, the desert climate is dominant and these countries are among the oil rich countries with high national income due to the high rent obtained from the oil. However, there is an antidemocratic structure of totalitarian regime in terms of democratic tendencies in these countries. Considered to be one of the most instable regions worldwide, the Middle East hosts countries having parallel structure in political and economic sense. Countries ruled by monarchy through the king and his relatives holding the governing power on one hand and the countries not ruled by monarchy, but by the presidents ruling authoritatively on the other hand are particularly remarkable. It is also understood that whether the countries ruled by monarchy or countries ruled by sham democracy, the common strategy of the rulers is to establish a constitutional structure to keep the public away from the administration and develop mechanism to hold the political and economic power in hand.

Looking closely at the Middle Eastern countries, the focal point of this study, as a whole it is obvious that the conditions of physical geography and the conditions of human and economic geography or physical geography and cultural geography are effective in the determination of the type of regimes. Consequently, human conditions shaped by the conditions of the cultural geography and the political culture shaped by it appear as a factor shaping the regimes in the Middle East. Hosting communities with different religious beliefs, ethnical qualities and cultures, the Middle East is at such a position that it creates common civilization basin of the humanity, showing developments and changes that deeply affect the world history. In addition to the positive characteristics such as religious, cultural and ethnical diversities, rich underground and ground resources and oil and natural gas reserves, negative characteristics such as economic problems, instable political culture not established on a certain system and autocratic structure make this region quite problematic and full of conflicts. On one hand, oil that becomes a strategic material in the course of time and the presence of $60 \%$ of the world petrol reserves in this region has caused the leading players of the world to give attention to this region. Especially oil dependency of the developed countries and thus desire to control the resources and occasional attempts of the oil-producing countries to use the oil as weapon have caused the people living in these countries to face a hot combat. Consequently, the rulers that desire to control such rich resources have elected to keep the public from the power mechanism.
Finally, the Arab Spring process that has driven the social dynamics in the Middle East has brought to the agenda of the internal politics and especially of the people the concepts such as social justice, requests of the youth, unbalanced distribution of population, unemployment, freedom, democratization, human resources and constitutional reforms Although this situation is not a regime-threatening issue for the Gulf monarchies now, the increased social and political requests pose a potential risk. On the other hand, in the countries such as Tunis, Egypt and Syria, movements to share the ruling authority started to be effective. Political stability in the region may be achieved by the public administrations and institutions responding to the requests of the peoples. Deficiency of democracy in the Middle East brings together with it the political, social and economic problems. It is possible that new political and economic crises may occur at any time immediately, further deepening the disagreements among the peoples living in the Middle East, a region considered as one of the most instable regions worldwide. However, despite of all of these, we should bear in mind that the institutions and rules of the democracy will become dominant in the Middle Eastern countries in the course of time.

\section{References}

[1] Akengin, H. Siyasi Coğrafya İnsan ve Mekân Yönetimi, PegemAkademi, 2012. Ankara.

[2] Carney, Richard W. "How Geograph Makes Democrac Work" Rajarainam School of İnternational Studies Singapore - RSIS WORKING PAPER; 10 December 2009.

[3] Akengin, H. Siyasi Coğrafya İnsan ve Mekân Yönetimi, PegemAkademi, 2012. Ankara.

[4] Akengin, H. Siyasi Coğrafya İnsan ve Mekân Yönetimi, PegemAkademi, 2012. Ankara.

[5] Democracy Index "A Report From The Economist Intelligence Unit”, http://www.eiu.com/, A.D.: 06/07/2013

[6] Carney, Richard W. "How Geograph Makes Democrac Work" Rajarainam School of International Studies Singapore - RSIS WORKING PAPER; 10 December 2009.

[7] Carney, Richard W. "How Geograph Makes Democrac Work" Rajarainam School of International Studies Singapore - RSIS WORKING PAPER; 10 December 2009.

[8] Ross, Micheal L. "Does Oil Hinder Democracy?" World Politics 53, April 2001, 325-361. http://www.rsis.edu.sg/publications/WorkingPapers/WP190. pdf, A.D.: 07/07/2013

[9] Staeheli, Lynn A. "Political Geography: Democracy and The Disorderly Public" Progress in Human Geography 34(1) (2010) pp. 67-78, DOI: 10.1177/0309132509105006

[10] Kasara, K. "Tax Me If You Can: Ethnic Geography, Democracy, and the Taxation of Agriculture in Africa" American Political Science Review, 2007. Vol. 101, No. 1 February 
[11] Staeheli, Lynn A. "Political Geography: Democracy and The Disorderly Public" Progress in Human Geography 34(1) (2010) pp. 67-78, DOI: 10.1177/0309132509105006

[12] Çalışkan, K. "Ortadoğu Siyaseti ve Toplumlarını Anlama Yolları", İstanbul Üniversitesi Siyasal Bilgiler Fakültesi Dergisi, October, 2008.Cilt. 39,

[13] Kışlakçı, T. Arap Baharı, 2011. İlimyurdu Yayıncılık, İstanbul

[14] Erdoğan, M. Anayasa Hukuku, Orion Yayınları, 2009. 5.Bask1 İstanbul.

[15] Sandıklı, A. ve Dağcı, K. Büyük Ortadoğu Projesi Yeni Oluşumlar ve Değişen Dengeler, 2006. İstanbul: Tasam Yayınları.

[16] Norton, A. R. and Kazemi, F. "Demokrasisiz Reform?" Yeni Yönelimler; Orta-doğu Politikaları ve Güvenlik, Augustos Richard Norton (der.), çev. Ceylan Tokluoğlu, 2000. Büke Yayınları, İstanbul.

[17] Kışlakçı, T. Arap Baharı, 2011. İstanbul: İlimyurdu Yayıncilik.

[18] http://www.ilkehaberajansi.com.tr/haber/ihvani-musliminsecimlerden-cekildi.html A.D.: 1/08/2013

[19] Kışlakçı, T. Arap Baharı, 2011. İstanbul: İlimyurdu Yayıncilik.

[20] Dursun, D. "Ortadoğu'nun Ekonomik, Sosyal ve Siyasi Yap1 Özellikleri Ü̈zerine Genel Tespitler" 2005. ,http://www.journals.istanbul.edu.tr/tr/index.php/sosy alsiyaset/article/view/ A.D.: 10/03/2013.
[21] Democracy Index "A Report From The Economist Intelligence Unit”, 2012.http://www.eiu.com/, A.D.: $06 / 07 / 2013$

[22] Metz, H. C. (1987). Iraq: A Country Study. GPO For the Library of Congress, Washington

[23] Akengin, H. Siyasi Coğrafya İnsan ve Mekân Yönetimi, 2012. PegemAkademi. Ankara.

[24] http://www.mfa.gov.tr/misir-siyasi-gorunumu.tr.mfa, A.D.: 29/03/ 2013.

[25] Metz, H. C. Iraq: A Country Study, 1987. GPO For the Library of Congress, Washington.

[26] http://www.mfa.gov.tr/misir-siyasi-gorunumu.tr.mfa, A.D.: 29/03/ 2013.

[27] Sait, Y. “Ortadoğu'ya Demokrasiyi Getirmek" International Journal of Economic and Administrati ve Studies. Year: 3 Number: 5, Summer 2010 ISSN 1307-9832

[28] Dursun, D “Ortadoğu'nun Ekonomik, Sosyal ve Siyasi Yap1 Özellikleri Üzerine Genel Tespitler", 2005. ,http://www.journals.istanbul.edu.tr/tr/index.php/sosy alsiyaset/article/view/ A.D.: 10/03/2013.

[29] Ataman, M. and Demir, G. N. "Körfez Ülkelerinin Ortadoğu Politikası ve Arap Baharına Bakışları", Seta Analiz, 2012. Say1: 52, October 2012. (www.setav.org, A.D.: 17/03/13.)

[30] Sözen, İ., Uslu K. and Öngel, V. "Ortadoğu ve Kuzey Afrika Ülkelerinin Rantiyeci Ekonomi Yapıları”, 2011. İstanbul Ticaret Üniversitesi Sosyal Bilimler Dergisi, Y11:10, Say1:19. 